\title{
China's Approach in Territorial Disputes Settlement
}

\author{
Taubayeva Zhazira Ayapbergenovna ${ }^{1}$ \\ ${ }^{1}$ L. Gumilyov Eurasian National University, Kazakhstan \\ Correspondence: Taubayeva Zhazira Ayapbergenovna, Kuishi Dina Street, 44, Astana, 010009, Kazakhstan. \\ E-mail: zhazira-t@mail.ru
}

Received: March 30, 2015 Accepted: May 20, 2015 Online Published: June 13, 2015

doi:10.5539/ass.v11n16p278

URL: http://dx.doi.org/10.5539/ass.v11n16p278

\begin{abstract}
China's growth to prominence in the international community after the end of the Cold War, the upturn in economic power and population numbers projects that China is able to become the leading world power within several decades, regardless of the course its government takes. The article aims to contribute in answering the question whether this rise will be peaceful through a comparative analysis of resolved and unresolved territorial disputes between China and groups of neighboring states between 1986 and 2014. While previous studies have focused rather exclusively on Chinese behavior, this text will examine both sides of the dispute and the parties' behavior in light of regional dynamics.
\end{abstract}

Keywords: China, territorial disputes, ASEAN, Asia-Pacific region

\section{Introduction}

The main theme of this article is the issue of China's emerging influence to the international community following the end of Cold War and whether this rise can be peaceful. Rapid economic growth and huge population reveals China as a leading world power within several decades.

It is historically accepted, that leading power transition has been accompanied by a war or an armed conflict as one nation seeks to preserve its hegemony and the worldwide system supporting its rules when an emerging nation seeks to maintain its influence on other spheres and take steps to assure international community in order to achieve its interests. This is the interpretation of realist theory in international relations. For instance, famous realist scholar J. Mearsheimer thinks that in the near future China can push the US government out of the vast region Asia Pacific (Mearsheimer, 2006). Despite the fact the US and China are contenders for global domination, there is also an issue that China has rival relations with other regional powers. To the north, it borders on Russia, which is emerging from the Soviet Union's collapse to the pivotal center of international politics. To the south, it faces India the world's most populous democracy, as a growing contender for regional leadership. To the southeast, China sees hostility of regional powers such as Japan, South Korea and Australia, and powerful group of nations - Association of Southeast Asian Nations (ASEAN). That is why the main task of China's government is to sustain in the face of its hostile neighboring countries and to improve its expansionist politics. China invests a great amount of its money to modernize its military build-up. Still in some territorial disputes, China has desisted from using force to get favourable goals than to make its neighbors weaker. In fact, these compromises have been achieved in several of territorial disputes. This study can be examined by the reasons why it's not working for other cases. Regional cooperation in Asia Pacific in international relations theory has been portrayed as difference expressed by a describing word view as one sees the nation-states as billiard balls (Krasner, 1982).

\section{Methodology}

This research use general and individual methods of scientific inquiry, in particular such methods as dialectics, system analysis, problem and chronology as well as geopolitical method. In the cases that will be described in this article, it becomes clear that all the states of the region should be taken into account. Any foreign policy move is restricted by internal issues and the acceptance of foreign policy results by the domestic audience (Putnam, 1988). Balancing actions within China as well as within regional nations are crucial to understand the dynamics that led to resolve not all the territorial disputes. In the conflicts analyzed in this paper, we review tensions within governments, for example rivalry of the countries in the South China Sea. 


\section{Overview of the Issues and Problems}

Territorial disputes have become one of the main factors for military conflicts between countries (Hensel, 2000), national borderlines may lose their importance, but they still can be a casus belli. Therefore border issues must be examined to avoid armed conflicts.

Nowadays, China is emerging to one of the powerful countries in the world, in this connection it is important to understand the steps China undertakes in many territorial disputes in order to prevent the full-scale conflict that all the revisionist politics supporters are still expecting. At the period of power transition under a multipolar world order, the study of peaceful settlement of the territorial disputes around China also can shed light on the cases when such transition can immediately lead to an armed conflict or what can avoid this. This study can help to give an answer through a comparative analysis of the territorial disputes settlement cases between China and other neighboring countries. It will be based on evidence from previous comparative analysis in works of Taylor Fravel (2008). The author mainly has discovered Chinese behaviour in different territorial disputes. It's plain to see that no dispute can be resolved without the actions of both sides and even small countries can be implacable on territorial issues. This study can examine the disputes through regional cooperation and multilateral negotiation process.

Territorial disputes prospective: main disputed areas. Controversy over territory have come to be seen as "the most crucial single cause of war between states in the last two or three centuries" (Luard, 2000). Many political scholars analyzed role of territorial disputes on regional cooperation and found out that territory matters for three reasons: "its tangible contents or attributes, its intangible or psychological value, and its effects on a state's reputation" (Hensel, 2000). This helps us to sketch the first autonomous variable and to build up first assumption:

\section{Autonomous variable 1. The importance of territory}

Assumption 1: The historical dependence of the attached territory to a given territorial dispute.

It is a big deal to designate values to a given part of territory. While territory or population numbers can be found, other potential sources of value such as the economic capability and the total volume of natural resources the area consists are not available. The factors of distance to centers of power cannot be easily estimated. Furthermore, advantages or disadvantages of state reputation in the area are not estimated to.

In terms of area, the disputed territories in Central and Northern Asia are far larger than the combined land area of the islands in the South China Sea. However, considering that control of the islands allows states to claim far ranging Exclusive Economic Zones (EEZs) in the South China Sea, the latter could be considered as the larger area under dispute. Nonetheless, we should keep in mind that for small states such as Tajikistan, the relatively small area under dispute constituted a sizeable portion of the country.

In terms of natural resources, while the South China Sea promises to contain large reserves of oil and fish resources, territories in Central Asia also contain hydrocarbons. The question of oil and gas exploration illustrates the problematic aspects of analysing territorial values for dispute resolution. Intransigence in territorial disputes over land containing oil and gas deposits does not actually yield access to these deposits. While China could begin drilling in the South China Sea, it is unlikely to gain international partners that could provide necessary technologies unless the dispute is settled. In Central Asia, the peaceful settlement of territorial issues has allowed China, Russia and the states of Central Asia to engage in far-reaching agreements over joint exploration of hydrocarbon resources. With reaching a compromise, China may have ceded a large part of disputed territory but has gained partners in its intensifying search for oil and gas (Lee, 2012). The benefits of territory can therefore not only be measured by the resources they contain as benefits achieved from cooperation can far outweigh the value of disputed territory. In this regard, the South China Sea is actually less valuable. Economic relations with Southeast Asian states are already established and are not contingent on dispute resolution. Even though escalations in the South China Sea could disrupt bilateral economic relations, the incidents over the last two decades have passed without serious disruptions.

Central Asian states had strong incentives to normalise their relations with China: economic aid, joint development of industry, and new export markets for natural resources and other goods for landlocked countries with few other close by markets and none as dynamically developing as China's. Central Asia has a geographic disadvantage compared to South East Asia; they are landlocked and thus less able to access international markets by sea. Overland, only Russia and China are close, while instability in Afghanistan prevents transit to South Asia. However, it is possible that the benefits are only tangible for elites. While national territory is traded away for other concessions, it is questionable, whether the population benefits or closely knit government circles, as the 
disagreements between Kyrgyzstans' President and Parliament illustrate. Nonetheless, the psychological value is equally shared between elites and population.

In terms of psychological value, the South China Sea seems to be more salient because of the high degree of politicisation of the dispute in China, Vietnam and the Philippines. The disputed territories in Central Asia were both far from Beijing and China's economic and population core along its eastern coastline. However, for Kazakhstan, Kyrgyzstan and Tajikistan, the disputed areas were part of their state core, while Russia saw its Far Eastern regions threatened by potential Chinese encroachment.

For these reasons, it is impossible to conclude that there is a marked difference in perceived value between the South China Sea and the territories in Central and Northern Asia. If only China's position is analysed, the latter territories are less valuable both economically and psychologically. And China's compromises in Central Asia can be somewhat explained by this variable. Nonetheless, Xinjiang and Manchuria (especially in its historical dimensions) cannot be discounted easily in value for Beijing. Additionally, if we take the attached values of states other than China into account, the value of territories loses its explanatory power. Related to the question of value as an explanatory factor is the type of territory under dispute. Quantitative studies show that territorial disputes are more likely to lead to militarised conflict and less likely to be settled peacefully than maritime or river disputes (Hensel et al., 2008).

An illustration can be found in the conflicts between China and Vietnam: The two countries fought a fierce border war in 1979. While the confrontation took place along a disputed border, it was not fought mainly for territorial reasons. China had a wider strategic objective of limiting Soviet and Vietnamese expansion in Southeast Asia, most recently in Cambodia, and launched the offensive (Rasler \& Thompson, 2008). As demonstrated above, neither the value nor the type of territory provide a sufficient explanation for the resolution of territorial disputes between China's northern neighbours and the irresolution of the South China Sea disputes.

Regional balance of power. Disagreements over territory do not exist in a void free from other political and strategic questions. While negotiators may be occupied solely with the dispute, leaders have to sign the agreements. Their decisions depend not only on the factors within the dispute but on larger questions affecting the situation of their states. One of these factors is the presence or absence of a strategic rivalry between the parties: "The prevailing idea that contested territorial claims emerge, lead to militarized uses of force when states assert contending claims, and then produce interstate rivalries that occasionally lead to war escalation is not in fact the norm. More commonly, we find that some territorial disagreements are embedded within rivalry contexts and that these are the ones that are most likely to develop into armed clashes" (Krauthammer, 1990). Therefore we can analyse whether strategic rivalries and balancing strategies explain the different outcomes found in the two cases.

\section{Autonomous Variable 2. Regional rivalry.}

Assumption 2: The stronger regional rivalry between countries to a territorial dispute, the less likely territorial disputes can be settled. In both of the two cases discussed above, strategic rivalries were present. The ideological and strategic struggle between the Soviet Union and China corresponded to decades of irresolution in their territorial dispute. Only with the impending collapse of the USSR a compromise solution became possible. Furthermore, as the strategic rivalry between Russia and China weakened, there emerged a shared concern over the predominance of the United States in the international system. This "unipolar moment" (Krauthammer, 1990) in the early 1990s, when the U.S. assumed a leading role as the remaining superpower, led Russia and China to look to each other as a counterbalance to the United States. This could mean that the stronger a strategic interest is shared between the parties to a dispute, the more likely a resolution is.

The predominance of the United States was not the only strategic concern shared between Russia, China and the states of Central Asia. As we have discussed in the case study above, the formation of the Shanghai Cooperation Organisation, while emerging from the boundary negotiations, is closely tied to a shared strategic concern with battling separatism and extremism in the region. Additionally, regional organisations create network effects that act in parallel to direct diplomatic ties, further strengthening shared strategic interests (Dorrusen \& Ward, 2008). In fact, the SCO can be understood as an alliance that conducts military exercises and aims to increase coordination potentials between the armed forces of regional states. While they are primarily directed against insurgencies, coordination effects apply on a broader scale (Castillo, 2008).

Therefore, the successful resolution process in China's border disputes with Russia and Central Asia could be understood as an effect of shared strategic interests. However, a central motive of regional cooperation in Central Asia is the stability of regimes (Ambrosio, 2008). Prior to U.S. involvement in Central Asia, unipolarity and the growth of the United States' status as a remaining superpower was not of much concern to the newly 
independent states of Central Asia. Even after September 11th, these states largely profited from U.S. presence both in terms of financial and military assistance as well as a balancing factor to the growth of Russian power in the region. While cooperation with China could be understood as a balancing strategy for Central Asian states that feared Russian predominance, the evidence of the negotiation process (which involved joint delegations under Russian leadership) as well as the emerging regional organisations (in which Russia is a leading member) points in the opposite direction. This means that, from a Central Asian perspective, the strategic rivalry factor is of secondary importance.

The case of the South China Sea provides better evidence for the importance of strategic rivalries. The leading regional format with ASEAN and China is often characterised as a strategic rivalry in itself. The smaller states of Southeast Asia prefer using the multilateral format offered by ASEAN to confront the regional superpower China (Tow \& Rigby, 2011).

This is particularly salient if the U.S. support for ASEAN members is taken into account. In 1951, the United States signed a mutual defence treaty with the Philippines and has extensive partnerships with Thailand. While the islands claimed by the in the South China Sea disputes are not covered by the agreement with the U.S., the strategic rivalry continues over the recent U.S. "pivot" to Asia and its continued support for Japan and Taiwan (Dzurek, 1995).

In China's disputes with Vietnam, the reduction of strategic rivalry after the colapse of the Soviet Union has led to almost immediate resumption of negotiations and the eventual conclusion of an agreement on the land border and the maritime boundary between the two countries in the Gulf of Tonkin (Vuving, 2006). Nonetheless, there were no negotiations concerning the status of the Paracel Islands, occupied by China in 1974 and continuing to be under its sole control.

The case of the South China Sea provides evidence to the importance of strategic rivalries in the resolution of territorial disputes. However, China has behaved differently in past disputes along its other borders. Comprehensive studies of China's behaviour have shown that concerns over regime security are the most important motivator for compromise and that alliances or open rivalries made little difference in Beijing's stance on territorial disputes (Fravel, 2005). Additionally, concerning the South China Sea we find that increased Chinese moderation seems to come as a response to increased US involvement in Asia. As Beijing is not willing to risk open confrontation with the United States over islands in the South China Sea, it has reduced its assertiveness over the island dispute. However, the main question is over how long this state of affairs will last.

There is a vibrant debate on whether China can be considered a "status-quo" power without territorial ambitions beyond its borders or whether it is a revisionist power seeking to expand its influence and become a regional or even global hegemon against the background of its growing economic and military power.

In the South China Sea, the strategic rivalry is not only based on historic claims but also on current strategic imperatives for China, the states of Southeast Asia and the United States. If the latter decides to see China's rise as a threat to its own interests and takes preventive measures, a self-fulfilling prophecy could be the result and China would become the antagonist feared by the U.S. (Friedberg, 1993).

If such a confrontation takes place, it will likely be played out in the South China Sea. There is ample evidence that the factor of strategic rivalry explains the lack of dispute resolution over the Paracel and Spratly Islands. At the same time, it only partially explains the success of dispute resolution in Central Asia, where a shared concern over regime security seems to have played a larger role.

\section{Autonomous variable 2. Regional security.}

It is difficult to measure regime security. However, we can point to events within the country that have made the government more or less secure in its position of power and legitimacy.

In the case of Central Asia, the Tiananmen Square demonstrations and uprisings in its predominantly ethnic Uighur region of Xinjiang have corresponded with Chinese compromises in territorial disputes in Central Asia. Additional evidence is provided by the fact that China was assured of Central Asian cooperation in limiting ethnic Uighur political groups at home in exchange for Chinese compromises on territory.

The regime security argument could also be applied to China's neighbours. In the case of the border negotiations in Central Asia, all sides' regimes were insecure, having just emerged into independence. The collapse of the Soviet Union has also led to a political and economic crisis in Russia at the beginning of the 1990s. Compared to the turmoil following the dismantling of the USSR, the regimes of Southeast Asia can be considered relatively stable. However, it does not appear that fluctuation in Southeast Asian regime security has affected the willingness of these states to compromise in territorial disputes in the South China Sea. The Philippines went 
through different administrations and moments of government crises, but with only marginal changes to its negotiating position in the South China Sea disputes. Vietnam has remained relatively stable, although the loss of the Soviet Union as a sponsor has led the country to be more open to negotiations with China over territory that did not include the islands in the South China Sea (Vuving, 2006).

Having already lost the Paracels in 1974, national sentiment is strongly clinging to the territories they still hold. Taiwan is preoccupied with the issues of its own sovereignty and largely aligns its claims to those of the PRC. The evidence so far is inconclusive and a closer examination of Southeast Asian countries is needed to ascertain whether they have changed their position as a result of fluctuations in regime security.

In conclusion, regime security remains the factor that best explains success in Central Asia's territorial disputes and provides a partial explanation for the lack of success in the South China Sea. However, a more thorough consideration of the other Southeast Asian states, Vietnam, Philippines, Malaysia, in this dispute is necessary to understand the impact of this variable. While observing China may yield valuable insights, we must not forget that there is more than one party to any territorial dispute, even though there may be vast power asymmetries between them.

\section{Conclusion}

The history of territorial disputes between China and its neighbours to the Northwest and Southeast illustrates the shortcomings of the arguments that China is an expansionist power seeking to regain lost territories. On the contrary, China seems to remain rooted in the mindset of a "satisfied empire with limited territorial ambitions" (Kissinger). Nonetheless, China has shown that it is willing and able to achieve its objectives by force, as was seen in the Sino-Soviet border clash of 1969 and the incident with Vietnam over the Paracel Islands. China's military build-up in the South China Sea can be seen as preparing for such a step by making it physically possible as well as by preparing the domestic audience for escalation.

However, this study has shown that other factors that an inherent expansionism plays a more important role in whether or not territorial disputes around China are resolved peacefully. The disputes in Central Asia and in the South China Sea have more in common than widely assumed. Similar obstacles existed in Central Asia to those that preclude a breakthrough in the disputes over the South China Sea. At the forefront is a shared interest for joint exploration of the resources these regions have to offer. While the settlement of border disputes paved the way for economic cooperation in Central Asia, economic partnerships in the South China Sea are already strong and growing despite latent tensions.

What seems to preclude the settlement of the South China Sea dispute is a wider strategic rivalry between ASEAN and China. However, we also need to take into account regime security factors for China and possibly other states in Southeast Asia. If the region experiences a crisis that limits the existing economic cooperation, the parties could be forced to come to agreement over the South China Sea. Joint development may become a necessity.

Confrontation between China and the United States over the South China Sea is not inevitable, as concerns over strategic rivalry can be overcome by phases of regime insecurity that prompt China, and possibly the other countries surrounding the South China Sea to an agreement. Further analysis of regime security dynamics in Southeast Asia could shed light on this problem but are beyond the scope of this study.

As this study has demonstrated, geostrategic rivalry and regional dynamics matter in the two cases. The implication for the wider discipline of peace and conflict studies is that other disputes may benefit from an analysis in a regional perspective, including not just the two sides but the wider international framework.

\section{References}

Ambrosio, T. (2008). Catching the "Shanghai Spirit": How the Shanghai Cooperation Organization Promotes Authoritarian Norms in Central Asia. Europe-Asia Studies, 60(8), 1321-1344. http://dx.doi.org/10.1080/ 09668130802292143

Castillo, A. (2008). SCO: Rise of NATO East?

Dorussen, H., \& Ward, H. (2008). Intergovernmental Organizations and the Kantian Peace: A Network Perspective. Journal of Conflict Resolution, 53(2), 189-212. http://dx.doi.org/10.1177/0022002707313688

Dzurek, J. (1995). China Occupies Mischief Reef in Latest Spratly Gambit.

Fravel, T. (2005). Regime Insecurity and International Cooperation: Explaining China's Compromises in Territorial Disputes. International Security, 30(2), 46-83. http://dx.doi.org/10.1162/016228805775124534 
Fravel, T. (2008). Strong Borders, Secure Nation: Cooperation and Conflict in China s Territorial Disputes. Princeton: Princeton University Press. http://dx.doi.org/10.1515/9781400828876

Friedberg, A. (1993). Ripe for Rivalry, Prospects for Peace in a Multipolar Asia. International Security, 18(3), 5-33. http://dx.doi.org/10.2307/2539204

Hensel, P. (2000). Theory and Evidence on Geography and Conflict. Boulder: Rowman and Littlefield.

Hensel, P., Mitchell, S., Sowers, T., \& Thyne, C. (2008). Bones of Contention: Comparing Territorial, Maritime and River Issues. The Journal of Conflict Resolution, 52(1), 117-143. http://dx.doi.org/10.1177/ 0022002707310425

Krasner, S. (1982). Regimes and the limits of realism: Regimes as autonomous variables. International Organisation, 36(2), 497-510. http://dx.doi.org/10.1017/S0020818300019032

Krauthammer, C. (1990). The Unipolar Moment. Foreign Affairs, 70(1), 23-33. http://dx.doi.org/10.2307/20 044692

Lee, J. (2012). China's Geostrategic Search for Oil. The Washington Quarterly, 35(3), 75-92. http://dx.doi.org/10. 1080/0163660X.2012.706510

Luard, E. (1970). The International Regulation of Frontier Disputes. Preager, 7.

Mearsheimer, J. (2006). China's Unpeaceful rise. Current History, 105(2), 160-162.

Putnam, R. (1988). Diplomacy and Domestic Politics: The Logic of Two-Level Games. International Organization, 42(3), 427-460. http://dx.doi.org/10.1017/S0020818300027697

Rasler, K., \& Thompson, W. (2006). Contested Territory, Strategic Rivalries and Conflict Escalation. International Studies Quarterly, 50(1), 145-167. http://dx.doi.org/10.1111/j.1468-2478.2006.00396.x

Tow, W., \& Rigby, R. (2011). China's Pragmatic Security Policy: The Middle-Power Factor. The China Journal, 65(2), 157-178.

Vuving, A. (2013). Strategic Evolution of Vietnam's China Policy: A Changing Mixture of Pathways. Asian Survey, 46(6), 805-824. http://dx.doi.org/10.1525/as.2006.46.6.805

Xiaoming, Z. (2005). China's 1979 War with Vietnam: A Reassessment. The China Quarterly, 184, 851-874. http://dx.doi.org/10.1017/S0305741005000536

\section{Copyrights}

Copyright for this article is retained by the author(s), with first publication rights granted to the journal.

This is an open-access article distributed under the terms and conditions of the Creative Commons Attribution license (http://creativecommons.org/licenses/by/3.0/). 